\title{
The Beneficial Effect Of Trifolium Flower Extracts On Paracetamol- Intoxicated Male Rats Ahkam M. El-Gendy
}

Zoology Dep. Faculty of science (Girls' branch), Al-Azhar University, Cairo, Egypt.

\section{Abstract \\ Background:}

Acetaminophen known as paracetamol (P) overdose can cause severe hepatotoxicity and even liver failure and hepatic centrilobular necrosis in experimental animals and humans.

\section{Material and methods:}

The male rats $(n=36)$ were allocated into 6 groups (each group $n=6$ rats). Group I was kept as control. All animals in groups II-VI were given paracetamol at $2 \mathrm{~g} / \mathrm{kg}$ bw by gastric gavage on days 3 post Trifolium alixanderanum ( $T$ alixanderanum) flower extracts (TEs) or N-acetylcystiene (NAC) treatments. Group III, IV and V were treated for three days by hexane extract $(\mathrm{THE}+\mathrm{P})$, ethanol extract $($ TEE + P) and water extract $($ TWE + P). Group VI received $100 \mathrm{mg} / \mathrm{kg}$ bw of antidote Nacetylcystiene $(\mathrm{NAC}+\mathrm{P})$.

\section{Results:}

Paracetamol induced a significant rise in Liver weight and hepatosomatic index, serum aspartate amino transferase (ASAT), alanine amino transferase (ALAT), alkaline phosphatase (ALP), total bilirubin (T bili), liver lipid peroxides (MDA+ 4-HDNE) with a reduction of liver glutathione (GSH), glutathione peroxidase (GSHpx) and superoxide dismutase (SOD) enzymes activities. The plant extracts showed a remarkable hepatoprotective and antioxidant activity against paracetamol induced hepatotoxicity as judged from the serum marker enzymes and antioxidant levels in liver tissues.

\section{Conclusion:}

The present investigation indicated that paracetamol damaged liver cells and TEs prevented this damage when compared with control group.Trifolium flower hexane extract was the most effective superior to TEE, TWE and NAC.

Key Words: Paracetamol, $T$ alixanderanum flower extracts, NAC, hepatosomatic index, ASAT, ALAT, ALP, GSH, MDA, Rattus rattus.

\section{Introduction}

Many herbal, medicinal and
pharmaceutical plants and their extracts are
widely studied by many researchers. Plant
derived natural products such as flavonoids,
terpenoids and steroids have received
considerable attention in recent years due to their diverse pharmacological properties including antioxidant and hepatoprotective activity (DeFeuids et al., 2003, Banskota et al., 2000 and Takeoka and Dao, 2003) Liver is a key 
organ regulating homeostasis within the body by various functions.

Liver injury caused by toxic chemicals and certain drugs has been recognized as a toxicological problem. Hepatotoxicity is one of very common aliment resulting into serious debilities ranging from severe metabolic disorders to even mortality (Patel et al., 2008).

Liver is the main organ which regulates many important metabolic functions. Hepatic injury is directly associated with these altered metabolic functions (Mitra et al., 1998). In past, several studies have been carried out to examine the effect of plants used traditionally by herbalists to support normal liver function and treat diseases of liver. So, various experimental evidences have confirmed the efficacy of plants such as Silybum marrium (milk thistle), Curcuma longa (turmeric) (Luper, 1999), Nymphea stellata (Bhandarkar et al., 2004). In spite of significant advances in medicinal plant research and rapid strides in modern medicine, we still are in need for more precise, safe and effective treatment of liver disorders (Oliveria $e t$ al., 2005).

Paracetamol is a widely used over-thecounter drug for analgesic and antipyretic effects. Its use in overdose (suicidal or accidental) or with chronic alcohol abuse causes fulminant liver failure (Prescott, 2000 and Gyamlani and Parikh, 2002). Paracetamol induced hepatic failure is the second leading cause of liver transplantation (Lee et al., 2004). In the initial phases of toxicity acetaminophen is metabolically activated by cytochrome P450 enzymes to a reactive metabolite, $\mathrm{N}$-acetyl-p- benzoquinone imine (NAPQI) that depletes GSH (Boelsterli and Lim, 2007).

$$
\mathrm{N} \text {-acetylcysteine (NAC), a cysteine }
$$
prodrug, has shown promise in numerous pathological conditions involving oxidative stress ((Vosters and Neve, 2002 and Kamboj et al.,2006a). As a sulphydryl donor NAC contributes to the regeneration of glutathione and by directly acting as a free radical scavenger (Aydin et al., 2002). Various studies have shown that NAC administration has a beneficial effect against oxidative stress in neurodegenerative diseases (Pocernich et al., 2001 and Kamboj et al., 2008).

Presently, N-acetylcysteine is the recommended clinical treatment for patients in danger of acetaminophen overdose-related hepatic toxicity. The mechanism of action of NAC is to increase glutathione levels in the hepatic cytosol and mitochondria thus detoxify the highly reactive and cytotoxic NAPQI formed via cytochromeP-450 2E1 (Grypioti, 2006). Other mechanisms, including improvement of tissue oxygen delivery and antioxidation activity, have also been identified for $\mathrm{N}$ acetylcysteine (Harrison et al., 1991).

Trifolium alixandrinum; Egyptian clover is also known as berseem clover. Egyptian clover is a most extensively planted crop and a major forage fed to livestock as hay, silage and pasture. Some Trifolium species such as Trifolium repens Lin., Trifolium arvense Lin., Trifolium pratense Lin. are used as expectorant, analgesic, antiseptic and tonic (Sabudak et al., 2009); also may be used for menopausal hot flashes (Booth et al., 2006); the pathological 
states associated with free radical overproduction e.g. diabetes (Mauri et al., 1999 and Amer et al., 2004) and possible anticarcinogenic implications (Nikkhah, 2012). Lin et al. (2004) found approximately 20 flavonoid glycoside malonates in the flower extract of red clover (Trifolium pratense L.).A recent study reported that red clover extract was composed of $35.54 \%$ isoflavones, $1.11 \%$ flavonoids, $\quad 0.06 \%$ pterocarpans, $\leq 0.03 \%$ coumarins, and $\leq 0.03 \%$ tyramine. Daidzein, genistein, formononetin, biochanin $\mathrm{A}$, coumestrol and naringenin (Booth et al., 2006). However no reports are available regarding the hepatoprotective activity of Trifolium alexandrinum Linn.flower extract. Keeping this fact in view the present study was undertaken to investigate the antioxidant and hepatoprotective activity of Trifolium alexandrinum Linn. extracts, against paracetamol induced hepatic damage in albino rat

\section{Material and methods}

$\mathrm{N}$-acetylcystiene and other chemicals were purchased from Sigma, St. Louis, MO, USA.

\section{Trifolium extracts:}

The plant flower samples were collected at flowering stage from local region during May. Extract of shade dried flowers were used. Five hundred grams dried flowers were soaked in 2 liters hexane at room temperature for 48 hours and filtered. The filtrate was dried at $30^{\circ} \mathrm{c}$ till concentrated to dark brownish semisolid residue. The supernatant was soaked in 2 liters ethanol at room temperature for 48 hours and filtered. The filtrate was dried at $30^{\circ} \mathrm{c}$ till concentrated to brownish semisolid residue. The supernatant was soaked in 2 liters distilled water at room temperature for 48 hours and filtered. The filtrate was dried at $80^{\circ} \mathrm{c}$ till concentrated to pale brownish semisolid residue.

Hexane and ethanol extracts were dissolved in a small amount of ethanol and diluted with water to adjust the concentration to 200mg/ ml.

Thirty six albino rats weighing between 150 to $180 \mathrm{~g}$ were used. They were kept under constant environmental and nutritional conditions throughout the experiment. The animals were allowed free feeding with a standard diet and drinking water ad libitum.

Animals were randomized and divided into six groups (I-VI) of six animals in each group. Group I was served as untreated control. Group II rats were treated with a single dose of paracetamol (2g/kg bw; Wagh, 2010) 24 hours before sacrificing. Group III - V were treated with $200 \mathrm{mg} / \mathrm{kg}$ bw of the flowers extracts (THE+P, TEE+P and TWE+P respectively). Group VI was treated with the NAC $(100 \mathrm{mg} / \mathrm{kg}$ bw). All treatments were used orally daily for three consecutive days. On the $3^{\text {rd }}$ day, one $h$ after the last doses of TEs and NAC, paracetamol suspension was given by oral route..The biochemical parameters were estimated after $24 \mathrm{~h}$ following the paracetamol dose.

\section{Sample collection:}

On $4^{\text {th }}$ day, animals of all groups were sacrificed after overnight fasting; twenty four hours after paracetamol treatment. Blood sample 
of each group was collected separately into sterilized dry centrifuge tubes and allowed to coagulate for $30 \mathrm{~min}$ at $37^{0} \mathrm{C}$. After centrifugation, sera were collected in vials and frozen until analysis. Liver tissue samples were collected for estimation of antioxidants and lipid peroxidation end product parameters and kept at $-20^{\circ} \mathrm{c}$ till analysis.

\section{Biochemical studies:}

The clear serum obtained after centrifugation was used for the estimation of serum ASAT, ALAT (Schumann et al., 2002); ALP (Tietz, 1982); and serum total bilirubin (Schlebusch et al., 1995).

Liver GSH contents, SOD activity were determined by the methods of Prince and Loose (1969) and Nishikimi et al. (1972) respectively. Hepatic GSHpx was measured according to the method of Ammerman, et. al. (1980) and Lipid peroxidation in the different tissues was estimated by colorimetric assay of malondialdhyde (MDA) + 4- hydroxynonenal (4- HDNE) as described by Esterbauer et. al. (1991), using kits from Wak- Chem Medical GMBH, Germany.

Statistical Analysis: All data were analyzed using one-way analysis of variance (ANOVA) with SPSS statistical software (SPSS, Inc., Chicago, IL). Pairwise comparisons between groups were performed using post hoc test. Significance was considered at $p \leq 0.05$. Data are presented as mean \pm standard deviation of the mean (SD).

\section{Results}

Liver weight and hepatosomatic index were significantly increased in paracetamolintoxicated group. These variances were returned back nearly to normal levels when rats treated with TEs or NAC for 3 days before paracetamol toxicity (table 1).

The concentration of some liver enzymes in serum were measured in rats undergoing treatments with paracetamol alone as well as those supplemented with TEs and NAC and in control rats. Enzymes assayed were ALAT, ASAT and ALP. Paracetamol administration produced significant increases $(\mathrm{p}<0.05)$ in ASAT; ALAT and ALP compared to the control group.

There were significant decreases $(\mathrm{p}<0.05)$ in ASAT; ALAT and ALP in the paracetamol + TEs or NAC compared to the paracetamol group.

As shown in table 1, total bilirubin increased significantly in paracetamol treated animals when compared with control group. TEs and NAC treatments three days before paracetamol toxicity succeeded in returning this elevation back nearly to normal level. 
Table (1): Body weight, liver weight, relative liver weight and liver function tests in different treated and control groups.

\begin{tabular}{|c|c|c|c|c|c|c|}
\hline Groups & $\mathbf{C}$ & $\mathbf{P}$ & THE+P & TEE+P & TWE+P & $\mathrm{NAC}+\mathrm{P}$ \\
\hline liver weight(g) & $\begin{array}{l}6.914 \pm \\
0.559\end{array}$ & $\begin{array}{c}10.429 \pm 0.845 \\
\mathrm{a}\end{array}$ & $\begin{array}{c}8.003 \pm 0.588 \\
\mathrm{ab}\end{array}$ & $\begin{array}{c}8.468 \pm \\
0.697 \\
a b\end{array}$ & $\begin{array}{c}9.002 \pm \\
0.924 \\
\text { ab }\end{array}$ & $\begin{array}{c}8.658 \pm 0.787 \\
a b\end{array}$ \\
\hline $\begin{array}{l}\text { Hepatosomatic } \\
\text { index }\end{array}$ & $4.13 \pm 0.26$ & $\begin{array}{c}6.30 \pm 0.70 \\
a\end{array}$ & $\begin{array}{c}4.85 \pm 0.44 \\
b\end{array}$ & $\begin{array}{c}5.09 \pm 0.35 \\
b\end{array}$ & $\begin{array}{c}5.42 \pm 0.41 \\
b\end{array}$ & $\begin{array}{c}5.15 \pm 0.34 \\
b\end{array}$ \\
\hline ASAT (U/L) & 41.6 & $\begin{array}{c}126.72 \pm 4.42 \\
\mathrm{a}\end{array}$ & $\begin{array}{c}48.41 \pm 2.56 \\
\mathrm{ab}\end{array}$ & $\begin{array}{c}51.88 \pm 2.81 \\
\mathrm{ab}\end{array}$ & $\begin{array}{c}55.23 \pm 3.59 \\
\mathrm{ab}\end{array}$ & $\begin{array}{c}44.15 \pm 3.10 \\
\mathrm{ab}\end{array}$ \\
\hline ALAT (U/L) & $25.92 \pm 1.54$ & $\begin{array}{c}67.77 \pm 4.31 \\
\mathrm{a} \\
\end{array}$ & $\begin{array}{c}31.26 \pm 2.01 \\
\mathrm{ab}\end{array}$ & $\begin{array}{c}33.76 \pm 3.78 \\
a b\end{array}$ & $\begin{array}{c}34.62 \pm 4.30 \\
a b\end{array}$ & $\begin{array}{c}30.58 \pm 2.73 \\
a b\end{array}$ \\
\hline ALP (U/L) & $\begin{array}{c}127.49 \pm \\
5.89\end{array}$ & $\begin{array}{c}279.34 \pm 7.32 \\
\mathrm{a}\end{array}$ & $\begin{array}{c}138.57 \pm 6.02 \\
\mathrm{ab}\end{array}$ & $\begin{array}{c}149.45 \pm \\
7.78 \\
\text { ab }\end{array}$ & $\begin{array}{c}153.60 \pm \\
5.19 \\
\text { ab }\end{array}$ & $\begin{array}{c}148.66 \pm 5.14 \\
a b\end{array}$ \\
\hline T bili.(mg/dl) & $0.17 \pm 0.01$ & $\begin{array}{c}0.28 \pm 0.06 \\
a\end{array}$ & $\begin{array}{c}0.19 \pm 0.01 \\
\mathrm{~b}\end{array}$ & $\begin{array}{c}0.19 \pm 0.02 \\
b\end{array}$ & $\begin{array}{c}0.20 \pm 0.02 \\
b\end{array}$ & $\begin{array}{c}0.18 \pm 0.01 \\
\mathrm{~b}\end{array}$ \\
\hline
\end{tabular}

Values are expressed as mean \pm SD for six animals in each group.

a $\mathrm{p}<0.05$ compared to the control, $\mathrm{b} p>0.05$ compared to paracetamol.

Table 2 showed the antioxidant parameters (GSH content, GSHpx and SOD activities) in the liver tissues. Paracetamol increased lipid peroxidation end product (MDA+ 4-HNE) and reduced antioxidant parameters (GSH content, GSHpx and SOD activities) in the liver tissues when compared with control group. TEs and NAC returned these changes back nearly to normal levels (Table 2).

Table (2): Some liver antioxidants and (MDA)+ 4- HNE in different treated and control groups.

\begin{tabular}{|c|c|c|c|c|c|c|}
\hline Parameters & C & $\mathbf{P}$ & THE $+P$ & TEE+P & TWE+P & $\mathrm{NAC}+\mathrm{P}$ \\
\hline $\mathrm{GSH}(\mu \mathrm{mol} / \mathrm{g})$ & 8.16 & $\begin{array}{c}1.938 \pm 0.275 \\
\mathrm{a}\end{array}$ & $\begin{array}{c}6.846 \pm 0.461 \\
\mathrm{ab}\end{array}$ & $\begin{array}{c}6.136 \pm 0.481 \\
\mathrm{ab}\end{array}$ & $\begin{array}{c}5.998 \pm 0.624 \\
a b\end{array}$ & $\begin{array}{c}8.096 \pm 0.872 \\
\mathrm{~b}\end{array}$ \\
\hline $\begin{array}{l}\mathrm{GSH}_{\mathbf{p x}} \\
\mathrm{U} / \mathrm{g})\end{array}$ & 594.99 & \begin{tabular}{|c|}
$329.39 \pm 37.91$ \\
$\mathrm{a}$ \\
\end{tabular} & $\begin{array}{c}473.42 \pm 41.40 \\
\mathrm{ab} \\
\end{array}$ & $\begin{array}{c}412.93 \pm 63.51 \\
\mathrm{ab} \\
\end{array}$ & $\begin{array}{c}393.12 \pm 23.16 \\
\mathrm{ab}\end{array}$ & $\begin{array}{c}446.94 \pm 38.27 \\
a b\end{array}$ \\
\hline $\begin{array}{l}\mathrm{OD}(\mathrm{U} / 100 \mathrm{~g} \\
\text { issue) }\end{array}$ & $\begin{array}{c}2934.83 \pm \\
432.22\end{array}$ & $\begin{array}{c}1328.33 \pm 95.83 \\
\mathrm{a}\end{array}$ & $\begin{array}{c}2704.17 \pm \\
570.34 \\
\text { b }\end{array}$ & $\begin{array}{c}2333.00 \pm \\
407.56 \\
\mathrm{ab}\end{array}$ & $\begin{array}{c}2316.00 \pm \\
424.94 \\
a b\end{array}$ & $\begin{array}{c}2731.33 \pm \\
385.55 \\
\text { b }\end{array}$ \\
\hline $\begin{array}{l}\mathrm{IDA}+4-\mathrm{HNE} \\
\text { umol/g) }\end{array}$ & $84.29 \pm 4.10$ & $\begin{array}{c}33.55 \pm 6.03 \\
\mathrm{a} \\
\end{array}$ & $\begin{array}{c}95.45 \pm 5.88 \\
a b\end{array}$ & $\begin{array}{c}93.81 \pm 7.01 \\
a b\end{array}$ & $\begin{array}{c}94.53 \pm 7.37 \\
a b \\
\end{array}$ & $\begin{array}{c}89.58 \pm 3.25 \\
a b\end{array}$ \\
\hline
\end{tabular}

Values are expressed as mean \pm SD for six animals in each group.

a p $<0.05$ compared to the control, $b \mathrm{p}>0.05$ compared to paracetamol.

\section{Discussion}

Drugs in common use can cause toxic effects on the liver. Hepatotoxicity produced by overdosing of paracetamol may serve as a model for toxic drug to the liver.

The liver has the fundamental role of deactivating all substances produced by toxic drugs (Larrey, 2003). However, to do so it needs vitaminic hepato-protective substances, such as those contained in phytotherapic products that medicine has known for thousands of years: Silybum marianum, Taraxacum officinale, Smilax aspera, Cynara scolymus, Salvia officinalis, Agropyrum repens, Hyssopus officinalis, Matricaria camomilla, Aloe species, etc... They are extremely effective on many 
degenerative or toxic processes for the liver. It has been reported that Trifolium contains flavonoids, triterpenoids and steroids (Booth et al., 2006). A number of scientific reports indicated certain flavonoids, triterpenoids and steroids have protective effect on liver due to its antioxidant properties )El- Hossary et al., 2000, DeFeudis et al., 2003 and Kumar et al., 2011). Presence of those compounds in TEs may be responsible for the protective effect on paracetamol-induced liver damage in rats.

It has been suggested that high dose of paracetamol causes increased production of free radicals, which may initiate lipid peroxidation of hepatic cell membrane, mitochondrial dysfunction, hepatocellular death and ultimately increase in liver weight )Murugaian et al., 2008). In this study, liver weight and hepatosomatic index increased significantly. However, Holt and Ju (2009) suggested that increased liver weight and increased serum bilirubin levels both of which are useful indicators of paracetamol induced hepatocellular damage.

In the present investigation, paracetamol administration resulted in elevated activities of ASAT, ALAT and ALP in serum against their respective control values. Similarly, serum total bilirubin level was also found to be increased significantly as a result of paracetamol toxicity. Elevated levels of serum enzymes are indicative of cellular leakage and loss of functional integrity of cell membrane in liver (Larrey, 2003). Hepatocellular necrosis leads to high level of serum markers in the blood, among these, aspartate transminase, alanine transaminase represents $90 \%$ of total enzyme and high level of alanine transminase in the blood is better index of liver injury (Ekam and Ebong, 2007). Increase in liver enzymes in serum following paracetamol administration has earlier been reported (Hardman et al., 1996 and Yapar et al., 2007). The elevation of the ASAT.ALAT and ALP values might be due to release of the enzymes from disrupted hepatic cells either due to necrosis or altered membrane permeability due to toxic effects of paracetamol. Similar elevations of these values in the paracetamol treated animals confirmed the findings of Bhaumik and Sharma (2002) in rabbits, Ekam and Ebong, (2007) in rats and Kanbur et al. (2009) in mice. The cumulative oxidative damage is likely one of the mechanisms producing the hepatotoxic effects of paracetamol administration in this study. The elevated levels of enzymes are decreased to near normal levels due to three days pre- treatment of Trifolium flower extracts indicated that it offered protection by preserving the structural integrity of the hepatocellular membrane against paracetamol.The molecular mechanism by which the TEs and NAC reduce liver damage maybe due to their antioxidant ability to maintain liver cell integrity even in the presence of a hepatotoxic agent such as paracetamol.

Serum bilirubin is one of the most sensitive tests employed in the diagnosis of hepatic diseases. The increase in total bilirubin in this study may be attributed to the inability of the damaged hepatic parenchymal cells to excrete the dye at normal rates (Bhaumik and Sharma, 2002). Administration of Trifolium 
flower extracrs decreased the level of serum total bilirubin suggesting that it offered protection. Many plant feeding and plant extractions were used in many other studies to decrease the levels of liver enzymes and bilirubin in paracetamol toxicity e.g, Plumbago zeylanica (Kanchana and Sadiq, 2011), Clitoria ternatea (Sarumathy et al., 2011) and oyster mushroom (Sumy et al., 2011)

Hepatic lipid peroxidation (LPO), expressed as MDA+ 4- HDNE, increased significantly in paracetamol toxicity. While, the activities of protective enzymes such as GSHpx and SOD and glutathione content in liver tissue were lowered after paracetamol administration. Enhanced LPO and reduced activities of GSHpx and SOD are indications of generation of free radical stress as a mark of hepatic damage due to paracetamol toxicity. Marked reductions in the activities of these free radical scavenging enzymes, GSHpx, associated with paracetamol toxicity were significantly reversed to normal on oral feeding of Trifolium flowers extracts as manner of the antilipid peroxidative ability to oxidative stress. (Boelsterli and Lim, 2007). Under conditions of NAPQI formation following toxic paracetamol high doses, GSH concentrations may be very low in the centrilobular cells, and the major peroxide detoxification enzyme, GSH peroxidase, which functions very inefficiently under conditions of GSH depletion (Hinson et al., 2004), is expected to be inhibited.

Trifolium flower hexane extract had the most protective effect followed by Trifolium flower ethanol extract against paracetamol toxicity. The protective activity of Trifolium flower water extract against the hepatotoxicity induced by paracetamol was the lowest in the present study. These results may be attributed to natural antioxidants in plants are usually fat soluble e.g vitamin E, A and polyphenols.

\section{Conclusion:}

It could be concluded that the biochemical alterations induced by administration of paracetamol; were improved under the effect of the used Trifolium flowers extract in a variable degrees. The most efficient was THE followed by TEE followed by NAC and TWE.

Further investigations into the appropriate isolation, characterization and concentration of the active constituents in Trifolium alixandrinum flowers extract are deemed necessary for elucidating their antihepatotoxic activity against paracetamol hepatotoxicity in rats.

The present study also suggests that concepts of traditional medicine have the potential to be transposed successfully in the context of modern medical interventions such as liver damage or toxicity.

\section{References}

Amer M, El-Habibi E and El-Gendy A (2004): Effects of Trifolium alexandrinum Extracts on Streptozotocin-Induced Diabetes in Male Rats. Ann Nutr Metab., 48:343-347.

Ammerman JP, Vhampman ML, Bouwman GW et al., (1980): Glutathione peroxidase. J. Animal Science., 51:1381.

Banskota AH, Tezuka Y, Adnyana IK et al., (2000): Hepatoprotective effect of Commbretum quadrangulare and its constituents. Biol Pharm Bull., 23:456- 60 .

Aydin S, Ozaras R, Uzun H, Belce A, Uslu E, Tahan V and Altug T, (2002): N-acetylcysteine reduced the effect of ethanol on antioxidant system in 
rat plasma and brain tissue. Tohoku J Exp Med., 198: 71-77.

Bhandarkar MR and khan A (2004): Antihepatotoxic effect of Nymphaea stellata willd., against carbon tetrachloride- induced hepatic damage in albino rats. J Ethnopharm., 9: 61-64.

Bhaumik A and Sharma MC (2002): Therapeutic Efficacy of Liv.52 in Paracetamol induced Hepatopathy in Rabbits. Indian J. Vetrin. Res., 11 (1): 8-17.

Boelsterli UA and Lim PL (2007): Mitochondrial abnormalities-a link to idiosyncratic drug hepatotoxicity? Toxicol Appl Pharmacol., 220:92107.

Boigk G, Stroedter L. Herbst H et al., (1997): Silymarin retards collagen accumulation in early and advanced biliary fibrosis secondary to complete bile duct obliteration in rats. Hepatology, 26(3): 643- 649. Booth NL, Overk CR, Yao P et al., (2006): The Chemical and Biological Profile of a Red Clover (Trifolium pratense) Phase II Clinical Extract.J Altern Complement Med; 12(2): 133-139.

DeFeuids FV, Papadopoulos V and Drieu K (2003): Ginko biloba extracts and cancer a research area in its infancy. Fundam Clin Pharamacol., 17:405 $-417$.

Ekam VS and Ebong PE (2007): Serum protein and enzyme livels in rats following administration of antioxidant vitamins during caffeinated and noncafeinated paracetamol induced hepatotoxicity. Nig J Physiol Scien., 22(1-2): 65-68.

El-Hossary GA, Selim MA, Sayed AE and Khaleel AE (2000): Study of the flavonoid content of Bassia muricata and Bauhinia racemosa. Bull Fac Pharm Cairo Univ., 38:93-97.

Esterbaur H, Schaur RJ And Zollner H, (1991): Chemistry and biochemistry of 4hydroxynonenal,and related aldhydes. Free radical. Bio Med., 4: 81-128.

Grypioti AD (2006) :Liver Oxidant Stress Induced By Paracetamol Overdose. Internet J Pharmacol.. 4 )2): $10 \mathrm{pp}$.

Gyamlani GG and Parikh CR (2002): Acetaminophen toxicity; Suicidal vs.accident. Critical Care, 6:155-159.

Hardman JG, Limbird LD and Gilman G (1996). The harmacological Basis of Therapeutics. McGraw Hill company, NY.

Harrison PM, Wendon JA, Gimson AE, Alexander GJ and Williams R (1991): Improvement by acetylcysteine of hemodynamics and oxygen transport in fulminant hepatic failure. $\mathrm{N}$ Engl J Med., 324:1852-1857.

Hinson JA, Reid AB, McCullough SS and James LP (2004): Acetaminophen-induced hepatotoxicity: role of metabolic activation, reactive oxygen/nitrogen species, and mitochondrial permeability transition. Drug Metab Rev., 36:805-822.

Kumar M, Phaneendra P, Bodhanapu S et al. (2011): Antioxidant and Hepatoprotective Activity of the Aqueous Extract of Myrtus Communis (Myrtle) Linn. Leaves Rupesh.Pharm., 1: 1083- 1090.

Kamboj, SS, Chopra, K and Sandhir, R (2008): Neuroprotective effect of $\mathrm{N}$-acetylcysteine in the development of diabetic encephalopathy in streptozotocin-induced diabetes. Metab Brain Dis; 23:427-443.

Kanbur M, Eraslan G, Beyaz L, Silici S, Liman BC and Atasever A (2009): The effects of royal jelly on liver damage induced by paracetamol in mice. Exper. Toxicol. Pathol., 61(2): 123-132.

Kanchana N and Sadiq M (2011): Hepatoprotctive effect of $\mathrm{P}$ lumbago zeylanica on paracetamol induced liver toxicity in rats. Int J Pharm Pharm Sci., 3 (1): 151-154.

Larrey D (2003): Drug induced liver disease. J Hepatol., 32:77 - 88.

Lee SST, Buters JTM, Pineau T et al., (1996): Role of CYP2E1 in hepatotoxiciy of acetaminophen, J Biolog Chem., 271, 12063-12067

Lin LZ, He XG, Lindenmaier M et al., (2000): Study of the flavonoids glycoside malonates of red clover (Trifolium pratense). J Agric Food Chem., 48(2) :354-365.

Luper S (1999): A review of plants used in the treatment of liver disease: part two, Altern Med Rev., 4: 178-188.

Mauri PL, Lemoli L, Gardana C et al., (1999): Liquid chromatography /electrospry ionization mass spectrometric characterization of flavonol glycosides in tomato extracts and human plasma. Rapid commun Mass Spectrum, 13: 924-931.

Mitra SK, Venkataranganna MV, Sundaram R, Gopumadhavan S (1998): Protective effect of HD03, a herbal formulation, against various hepatotoxic agents in rats, J Ethnopharm; 63:181-186.

Murugaian P, Ramamurthy $\mathbf{V}$ and Karmegam $\mathbf{N}$ (2008): Hepatoprotective activity of Wedelia calendulacea L. against acute hepatotoxicity in rats. Res J Agricult Biol Sci., 4(6): 685-687.

Nikkhah A (2012): Legumes Biofarming and Biopharmaceutical Sciences: A Review. Res J Medici Plant, 6: 466-488.

Nishikimi M, Rao, NA and Yagl, K (1972): The occurance of superoxide anion in the reaction of reduced phenazine methosulpharee and molecular oxygen. Biochem Biophys Res., 46: 844-853.

Patel RK, Patel MM, Patel MP, Kanzaria NR, Vaghela KR, Patel NJ (2008): Hepatoprotective activity of Moringa oleifera Lam. Fruit on isolated rat hepatocytes. Phcog mag., 4:118 - 23.

Prins, HK and Loose, JA (1969): Glutathione, In: " Biochemical methods in red cell genetics" Chapter 40.(edited by Yunis, J.J.), Academic press, N.Y. London pp. 126-129.

Pocernich CB, Cardin AL, Racine CL, Lauderback CM and Butterfield DA (2001): Glutathione elevation and its protective role in acrolein-induced protein damage in synaptosomal membranes: relevance to brain lipid peroxidation in 
neurodegenerative disease. Neurochem Int., 39: 141149.

Olivera FA, Chaves MH, Almedia FRC et al., (2005): Protective effect of $\alpha-$ and $\beta$ - amyrin, a triterpene mixture from Protium heptaphyllum (Aubl.) March. Trunk wood resin, against acetaminophen -induced liver injury in mice, J Ethnopharm., 98: 103-108.

Prescott LF (2000): Paracetamol, alcohol and the liver, British J Pharmacol., 49: 291-301.

Reid AB, Kurten RC, McCullough SS, Brock RW, Hinson JA (2005): Mechanisms of acetaminopheninduced hepatotoxicity: role of oxidative stress and mitochondrial permeability transition in freshly isolated mouse hepatocytes. J Pharmacol Exp Ther., 312:509-516.

Sabudak T, Ozturk M, Goren AC, Kolak U and Topcu G (2009): Fatty acids and other lipid composition of five Trifolium species with antioxidant activity. Pharmaceut Biol., 47(2): 137141.

Sarumathy K, Rajan D Vijay T and Jayakanthi T (2011): Evaluation of phytoconstituents, nephroprotective and antioxidant activities of Clitoria ternatea. J Applied Pharmac Scie., 1 (5): 164-172.

Schlebusch H, Schneider C and Liappis N (1995): Bilirubin determination in neonatal sera: Precision accuracy and sensitivity to hemoglobin interferences of six runtime methods. Clin Chem., 6: 95-95.

Schumann G, Bonora R, Ceriotti F et al., (2002): IFCC primary reference procedures for the measurement of catalytic activity concentrations of enzymes at $37{ }^{\circ} \mathrm{C}$ : Part 4. Reference procedure for the measurement of catalytic concentration of alanineaminotransferase. Clin. Chem Lab Med., 40: 718-724.

Schumann G; Bonora R; Ceriotti F et al., (2002): IFCC primary reference procedures for the measurement of catalytic activity concentrations of enzymes at $37{ }^{\circ} \mathrm{C}$ : Part 5. Reference procedure for the measurement of catalytic concentration of aspartate-aminotransferase. Clin. Chem Lab Med., 40: $725-733$

Sumy AK, Jahan N, Sultana N and Amin R (2011): Effect of Oyster Mushroom (Pleurotus Florida) on Paracetamol Induced Changes of serum bilirubin level and liver tissue protein in Rats. J Bangladesh Soc Physiol., 6(1): 10-15.

Takeoka GR and Dao LT (2003): Antioxidant constituent of almond (Prunus dulcis (Mill.) D.A.Webb) hulls. J Agri Food Chem., 51: 496-501.

Vholt $M$ and Ju C (2009): Drug induced liver injury. In: J Uetrecht, editor. Adverse Drug Reaction. Springer Heidelberg Dordrecht London.

Vosters O, Neve J (2002): Inhibitory effects of thiolcontaining drugs on erythrocyte oxidative damages investigated with an improved assay system. Talanta., 57:595-600.

Watkins PB and Seef LB (2006): Drug induced liver injury: Summary of a single topic research committee. Hepatology, 43:618 - 31.

Wagh SS (2010): Antioxidant and Hepatoprotective Activity of Tridax Procumbens Linn, against Paracetamol induced Hepatotoxicity in Male Albino Rats. Advanc Stud Biol., 2(3): 105-112.

Wolf A, Diez - Fernadez C, Trendelenburg CF, Prieto P, Hary S and Trammer WE (1997): Paracetamol induced oxidative stress in rat hepatocytes. J Pharm Exp Ther., 280:1328 - 34.

Yapar K, Kart A, Karapehlivan M, Atakisi O, Tunca R, Erginsoy S, and Citil M (2007): Hepatoprotective effect of L-carnitine against acute acetaminophen toxicity in mice Exper Toxicolog Pathol., 59(2):121-128. 


\section{التأثير المفيد لخلاصة زهور البرسيم على الجرذان المسممة بالباراسيتامول أحكام محمود الجندي$$
\text { قسم علم الحيوان ـ كلية العلوم (بنات)- جامعة الأزهر - القاهرة - مصر }
$$

\section{ملخص}

الجر عات الزائدة من البار اسيتامول تسبب تسم كبدي شديد في الإنسان و الحيو ان.وقد بذلت محاو لات كثيرة للحد

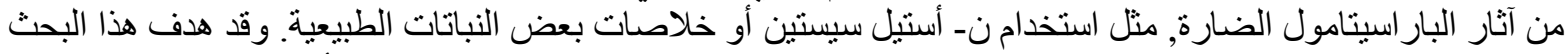

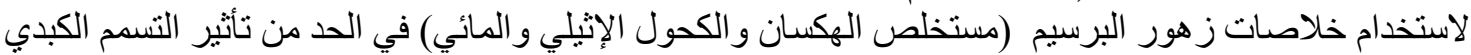
بالبار اسيتامول وقد قورنت النتائج مع ن- أستيل سيستين.

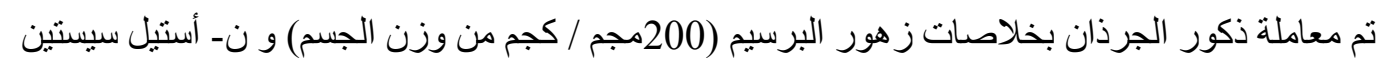
(100مجم/ كجم من وزن الجسم لمدة ثلاثة أيام قبل الحقن بجر عة كبيرة من البار اسيتامول (2جم/كجم من وزن الجسم),



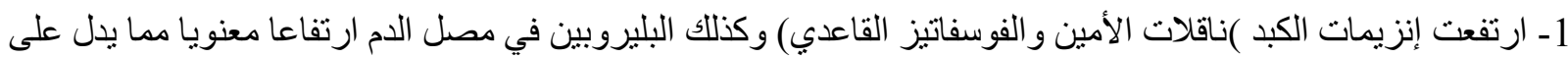

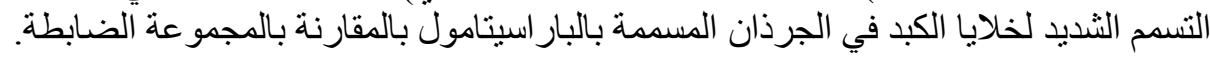



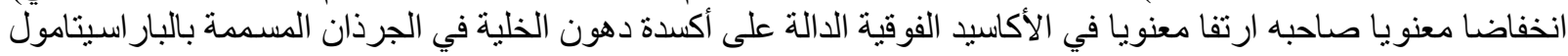
بالمقارنة بالمجمو عة الضابطة.

3- كان تأثير خلاصة الركسان لزهور البرسيم أكثر فعالية من خلاصـة الكحول الإثيلي وال نـ أستيل سيستين, والخلاصة

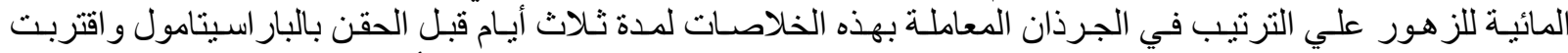

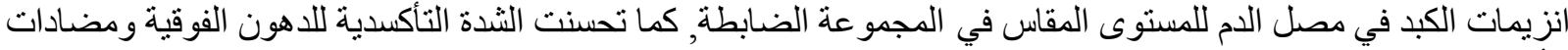

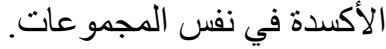

ويستخلص من البحث فو ائد خلاصة زهور البرسيم للحد من أضر ار التسمم الكبدي بالبار اسيتامول وبديل جيد للا.

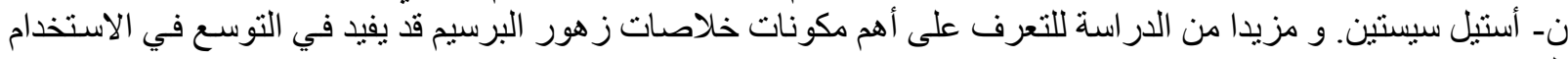
العلاجي. 